\title{
Expression profiles associated with aggressive behavior in Merkel cell carcinoma
}

\author{
María-Teresa Fernández-Figueras ${ }^{1}$, Lluís Puig², Eva Musulén ${ }^{1}$, Montserrat Gilaberte ${ }^{3}$, \\ Enrique Lerma ${ }^{4}$, Sergio Serrano ${ }^{5}$, Carlos Ferrándiz ${ }^{6}$ and Aurelio Ariza ${ }^{1}$ \\ ${ }^{1}$ Department of Pathology, Hospital Universitari Germans Trias i Pujol, Autonomous University of Barcelona, \\ Barcelona, Spain; ${ }^{2}$ Department of Dermatology, Hospital de la Santa Creu i Sant Pau, Autonomous \\ University of Barcelona, Barcelona, Spain; ${ }^{3}$ Department of Dermatology, Hospital del Mar, Autonomous \\ University of Barcelona, Barcelona, Spain; ${ }^{4}$ Department of Pathology, Hospital de la Santa Creu i Sant Pau, \\ Autonomous University of Barcelona, Barcelona, Spain; ${ }^{5}$ Department of Pathology, Hospital del Mar, \\ Autonomous University of Barcelona, Barcelona, Spain and ${ }^{6}$ Department of Dermatology, Hospital \\ Universitari Germans Trias i Pujol, Autonomous University of Barcelona, Barcelona, Spain
}

\begin{abstract}
Primary neuroendocrine carcinoma of the skin, or Merkel cell carcinoma, is the most aggressive cutaneous neoplasm. In spite of its similarities to small cell carcinomas from other locations, Merkel cell carcinoma shows many peculiarities probably related to its epidermal origin and the etiologic role of UV radiation. We have immunohistochemically investigated 43 markers on a tissue microarray in which 31 surgically resected Merkel cell carcinomas were represented. Of these, 15 patients remained free of disease after removal, whereas 16 developed metastases. Immunoreactivity was scored according to staining intensity and the percentage of positive cells. We found statistically significant correlations between metastatic tumor spread and overexpression of matrix metalloproteinase (MMP) 7, MMP10/2, tissue inhibitor of metalloproteinase 3, vascular endothelial growth factor (VEGF), P38, stromal NF-kappaB, and synaptophysin. Also detected were statistically significant correlations between the expression levels of MMP7 and VEGF, MMP7 and P21, MMP7 and P38, MMP10/2 and VEGF, P38 and synaptophysin, P38 and P53, and P21 and stromal NF-kappaB. These findings may be helpful in predicting the clinical course of Merkel cell carcinoma and are potentially useful for the development of targeted therapies.
\end{abstract}

Modern Pathology (2007) 20, 90-101. doi:10.1038/modpathol.3800717; published online 17 November 2006

Keywords: carcinoma; Merkel; neuroendocrine; prognosis; skin; tissue microarray

Merkel cell carcinoma, a primary neuroendocrine carcinoma of the skin, is a rare neoplasm that probably originates from a primitive pluripotential epidermal cell. ${ }^{1}$ Similar to the small cell neuroendocrine carcinomas from other locations, Merkel cell carcinoma is a highly malignant neoplasm, being considered the most aggressive primary cancer of the skin. ${ }^{2-4}$ The prognosis of Merkel cell carcinoma, however, is relatively favorable when compared to extracutaneous small cell carcinoma. ${ }^{5}$ In addition to morphological similarities, Merkel cell carcinoma and extracutaneous small cell carcinoma also

Correspondence: Dr MT Fernández-Figueras, MD, Department of Pathology, Hospital Universitari Germans Trias i Pujol, Autonomous University of Barcelona, Carretera de Canyet, Badalona, Barcelona 08916, Spain.

E-mail: 20669mtf@comb.es

Received 1 August 2006; revised 2 October 2006; accepted 3 October 2006; published online 17 November 2006 exhibit genetic analogies such as their cell cycle and apoptosis-related molecular profiles. ${ }^{6,7}$

In a previous work of ours, ${ }^{7}$ the only significant difference between Merkel cell carcinoma and extracutaneous small cell carcinoma was a higher Ki67 proliferation rate in the latter, a finding that would partly explain their different behaviors. Moreover, among Merkel cell carcinomas an elevated Ki67 proliferation rate was associated with a trend to metastasize and kill the patient. ${ }^{7,8}$ Nevertheless, differences in proliferation rate do not entirely explain the variable clinical courses of skin tumors. Cutaneous squamous cell carcinoma, like extracutaneous small cell carcinoma, shares with Merkel cell carcinoma some genetic abnormalities, but commonly exhibits a relatively indolent behavior in spite of its very high proliferation rate. ${ }^{9}$ As altered cell cycle or apoptosis mechanisms do not seem to have a decisive impact on Merkel cell carcinoma biologic behavior, other factors must condition the aggressive evolution of this neoplasm. 
The present work intended to explore the prognostic impact exerted on Merkel cell carcinoma by the expression of various molecules, which are involved in tumor invasion and angiogenesis and belong to cell activation signaling pathways such as the mitogen-activated protein kinase (MAPK) and AKT pathways. Specifically, we focused on the study of matrix metalloproteinases (MMPs), a family of zincdependent endopeptidases capable of degrading the extracellular matrix ${ }^{10}$ and tissue inhibitors of metalloproteinases (TIMPs). Additionally, we investigated some other carcinogenesis-related molecules so far unexplored in Merkel cell carcinoma and assessed the influence of neuroendocrine differentiation on the evolution of Merkel cell carcinoma.

Differential expression of the aforesaid molecules was immunohistochemically evaluated using tissue microarray technology, a simple method allowing the application of numerous antibodies to case series with economy of time and reagent consumption, facilitating maximum preservation of paraffinembedded tissue as well. ${ }^{11}$ Previous results demonstrated excellent agreement rates between whole section and tissue array analyses. ${ }^{12}$ A further aim of the study was to look for potentially valuable targets of new treatments, as the survival benefit offered by adjuvant therapy to patients with advanced stage Merkel cell carcinoma is very limited at the present time.

\section{Materials and methods}

\section{Samples}

Paraffin blocks corresponding to 31 consecutive cases of Merkel cell carcinoma were retrieved from the files of the Departments of Pathology, Hospital Germans Trias i Pujol, Hospital de la Santa Creu i Sant Pau, Hospital del Mar and Hospital de la Creu Roja, Barcelona, Spain. All tissue specimens had been fixed in buffered formalin and routinely processed. The clinical course as regards development of regional and distant metastases and survival was recorded for all Merkel cell carcinoma cases. Of the 31 Merkel cell carcinoma patients, 15 were free of disease on last follow-up whereas 16 had developed metastases. Four lymph nodes showing Merkel cell carcinoma metastases were also included in the study and four cases of lung or urinary bladder extracutaneous small cell carcinoma were selected as controls. Pathological diagnoses were based on microscopic study of hematoxylin-eosinstained sections. Diagnostic confirmation was provided by immunohistochemical paranuclear dotlike positivity for neuroendocrine markers and low molecular weight keratins. Immunohistochemical investigation of keratin 7 , keratin 20, and TTF-1 expression helped to distinguish Merkel cell carcinoma from metastatic extracutaneous small cell carcinoma in doubtful instances. Merkel cell carcinoma paraffin blocks containing necrotic or poorly preserved tissue were excluded. None of our cases showed combined cutaneous squamous cell carcinoma and Merkel cell carcinoma.

\section{Tissue Microarray}

Hematoxylin-eosin-stained slides and Ki67 immunostainings of all cases were reviewed by two researchers (MTFF and MG), who marked wellpreserved areas. Tissue corresponding to these areas was randomly sampled from paraffin blocks, with no special preference for the different parts of the tumor (eg, superficial zone vs infiltrating border). Two cylindrical cores, each measuring $0.6 \mathrm{~mm}$ in diameter, were obtained from every donor block using a tissue microarray workstation MTA-1 (Beecher Instruments, Silver Spring, MD, USA). Cylinders, including those from extracutaneous small cell carcinoma control cases, were arrayed in a new paraffin block. In order to validate whether the tissue array was representative, the proliferation rates (percentage of Ki67-positive tumor cells) obtained with the whole sections were compared with the tissue array values. The concordance was complete in $87 \%$ of cases, whereas a difference under $8 \%$ was registered in $10 \%$ of instances. A difference of $18 \%$, observed in just one case, was attributed to the presence of extensive necrosis in the whole section.

\section{Antibodies and Immunohistochemical Studies}

Table 1 summarizes the antibodies utilized and their suppliers, as well as the parameters used for evaluation. Five micrometers thick sections were deparaffinized, hydrated, immersed in buffered citrate, and autoclaved. Afterwards, sections were incubated for $30 \mathrm{~min}$ in rabbit serum. Incubations with primary antibodies were carried out for $22 \mathrm{~h}$ at room temperature. Slides were washed and incubated with biotinylated rabbit anti-mouse Ig antibodies at a 1:700 dilution and then incubated in $\mathrm{PBS} / 6 \%$ hydrogen peroxide for $15 \mathrm{~min}$ at room temperature before addition of avidin-biotin peroxidase complex (Dakopatts, Glostrup, Denmark). The chromogen 3,3'-diaminobenzidine tetrachloride (Serva, Heidelberg, Germany) was applied, and counterstaining was performed with Harris hematoxylin. A non-immune mouse serum was used as a negative control. Quantification of the results was adapted to the staining patterns of each antibody. For markers such as P53 where the staining was uniformly strong, only the percentage of positive cells was evaluated. Conversely, intensity of staining was the only parameter considered for markers like PTEN, whereas in positive cases the staining was diffuse. Nevertheless, for most markers, both percentage of positive cells and intensity of staining were evaluated. The composite scores used for intensity and percentage are specified in the 
Table 1 Antibodies, suppliers, dilutions, and techniques used for immunohistochemistry and parameters evaluated

\begin{tabular}{|c|c|c|c|c|}
\hline Antibody & Source & Dilution & Technique & Parameters evaluated \\
\hline $\begin{array}{l}\text { Anti-human chromogranin A, mouse } \\
\text { monoclonal antibody }\end{array}$ & Dako, Glostrup, Denmark & 1:600 (EDTA) & $\begin{array}{l}\text { Dako } \\
\text { Autostainer }\end{array}$ & Percentage $^{\mathrm{a}}$ \\
\hline Synaptophysin, mouse monoclonal antibody & Biogenex, San Ramón, CA, USA & $1: 100$ & $\begin{array}{l}\text { Dako } \\
\text { Autostainer }\end{array}$ & $\begin{array}{l}\text { Percentage and intensity } \\
\text { and percentage } \\
\text { (low: } \leq 10 \% \text { of cells } \\
\text { high: }>10 \% \text { of cells) }\end{array}$ \\
\hline CD56 (NCAM), mouse monoclonal antibody & $\begin{array}{l}\text { Novocastra, Newcastle upon Tyne, } \\
\text { UK }\end{array}$ & $1: 50$ & $\begin{array}{l}\text { Dako } \\
\text { Autostainer }\end{array}$ & Percentage and intensity ${ }^{\mathrm{b}}$ \\
\hline $\begin{array}{l}\text { Anti-human cytokeratin } 20 \text {, mouse } \\
\text { monoclonal antibody }\end{array}$ & Dako & $1: 50$ & $\begin{array}{l}\text { Dako } \\
\text { Autostainer }\end{array}$ & $\begin{array}{l}0:<1 \% \text { of cells } \\
1:>1 \% \text { of cells }\end{array}$ \\
\hline p21protein, mouse monoclonal antibody & $\begin{array}{l}\text { Santa Cruz Biotechnology, Santa } \\
\text { Cruz, CA, USA }\end{array}$ & $1: 30$ & $\begin{array}{l}\text { Dako } \\
\text { Autostainer }\end{array}$ & Percentage $^{\mathrm{a}}$ \\
\hline $\begin{array}{l}\text { p53 protein (clone DO7), mouse monoclonal } \\
\text { antibody }\end{array}$ & Novocastra & $1: 500$ & $\begin{array}{l}\text { Dako } \\
\text { Autostainer }\end{array}$ & Percentage $^{a}$ \\
\hline $\begin{array}{l}\text { Anti-human Bcl-2 oncoprotein, mouse } \\
\text { monoclonal antibody }\end{array}$ & Dako & $1: 350$ & Ventana, Nexes & Percentage and intensity ${ }^{\mathrm{b}}$ \\
\hline $\begin{array}{l}\text { Anti-human Bcl-6 protein, mouse monoclonal } \\
\text { antibody }\end{array}$ & Dako & $1: 30$ & Ventana, Nexes & Percentage and intensity ${ }^{\mathrm{b}}$ \\
\hline CD117 (c-kit), rabbit polyclonal antibody & Dako & $1: 50$ & Ventana, Nexes & Percentage $^{a}$ \\
\hline PTEN (A2B1), mouse monoclonal antibody & Santa Cruz Biotechnology & $1: 50$ & Ventana, Nexes & Intensity $^{\mathrm{c}}$ \\
\hline $\begin{array}{l}\text { NF-kappaB/p50 Ab-2, rabbit polyclonal } \\
\text { antibody }\end{array}$ & Neomarkers, Fremont, USA & $1: 40$ & Ventana, Nexes & $\begin{array}{l}\text { Percentage and intensity }{ }^{\mathrm{b}} \text { evaluated } \\
\text { in tumor and in estroma }\end{array}$ \\
\hline
\end{tabular}

Survivin (FL-142) SC-10811, rabbit polyclonal

Phospho-p38 MAPK (Thr180/Tyr182) 28B10, mouse monoclonal antibody

Prostaglandin E synthase (microsomal), rabbit polyclonal antibody

Prostaglandin E synthase-2 (microsomal),

rabbit polyclonal antibody

HIF- $1 \alpha$, mouse monoclonal antibody

Vascular endothelial growth factor (VEGF) epitope-specific, rabbit polyclonal antibody

FLK-1 (A-3), mouse monoclonal antibody

Matrix metalloproteinase 1, mouse

monoclonal antibody

Matrix metalloproteinase 2, mouse

monoclonal antibody

MMP3 (stromelysin-1) Ab-2 (clone SL-1 IID4), mouse monoclonal antibody

MMP7 (matrilysin) Ab-1 (clone ID2), mouse

monoclonal antibody

Matrix metalloproteinase 9, mouse

monoclonal antibody

MMP10-2 (stromelysin-2) Ab-2 (clone IVC5), Neomarkers

mouse monoclonal antibody

MMP10-5 (stromelysin-2) Ab-5, rabbit Neomarkers

polyclonal antibody

MMP13 (collagenase-3) Ab-1 (clone VIIIA2), Neomarkers

Cell Signaling, Danvers, MA, USA 1:40

Cayman, Massy, France

Cayman, Massy, France

BD Biosciences, San José, CA, USA 1:20 (buffer+LSAB)

MD, Granada, Spain

Santa Cruz

Novocastra

Novocastra

Neomarkers

Neomarkers

Neomarkers

mouse monoclonal antibody
$1: 300$

$1: 380$

$1: 20$

Dako

Autostainer

Ventana, Nexes

Ventana, Nexes

Ventana, Nexes

LSAB+System-HRP, Dako LSAB+System-HRP, Dako

Ventana, Nexes

LSAB+System-HRP, Dako

LSAB+System-HRP, Dako

$1: 10$

Prediluted (buffer)

Prediluted (buffer)

LSAB+System-HRP, Dako

Ventana, Nexes

Prediluted (buffer) Ventana, Nexes

Prediluted (buffer)

Prediluted (buffer)

Prediluted (buffer)

LSAB+System-HRP, Dako

Ventana, Nexes

in tumor and in estroma

Percentage and intensity

Percentage and intensity

Percentage and intensity

Percentage and intensity ${ }^{\mathrm{b}}$

Intensity ${ }^{\mathrm{c}}$

0: absent; $1:<50 \% ; 2:>50 \%$

Percentage and intensity

Percentage and intensity

Percentage and intensity

Percentage and intensity ${ }^{\mathrm{b}}$

Percentage and intensity ${ }^{\mathrm{b}}$

Percentage and intensity ${ }^{\mathrm{b}}$

Percentage and intensity

Percentage and intensity ${ }^{\mathrm{b}}$

Percentage and intensity ${ }^{\mathrm{b}}$ 
Table 1 Continued

\begin{tabular}{|c|c|c|c|c|}
\hline Antibody & Source & Dilution & Technique & Parameters evaluated \\
\hline $\begin{array}{l}\text { MMP14/MT1-MMP Ab1, rabbit polyclonal } \\
\text { antibody }\end{array}$ & Neomarkers & Prediluted (buffer) & LSAB+System-HRP, Dako & Percentage and intensity ${ }^{\mathrm{b}}$ \\
\hline $\begin{array}{l}\text { MMP15/MT2-MMP Ab1, rabbit polyclonal } \\
\text { antibody }\end{array}$ & Neomarkers & Prediluted (buffer) & LSAB+System-HRP, Dako & Percentage and intensity ${ }^{\mathrm{b}}$ \\
\hline $\begin{array}{l}\text { MMP16/MT3-MMP Ab1, rabbit polyclonal } \\
\text { antibody }\end{array}$ & Neomarkers & Prediluted (buffer) & LSAB+System-HRP, Dako & Percentage and intensity ${ }^{\mathrm{b}}$ \\
\hline $\begin{array}{l}\text { Matrix metalloproteinase } 19 \text {, mouse } \\
\text { monoclonal antibody }\end{array}$ & Novocastra & $1: 10$ & LSAB+System-HRP, Dako & Percentage and intensity ${ }^{\mathrm{b}}$ \\
\hline $\begin{array}{l}\text { Matrix metalloproteinase } 23 \text {, mouse } \\
\text { monoclonal antibody }\end{array}$ & Novocastra & Prediluted (buffer) & LSAB+System-HRP, Dako & Percentage and intensity ${ }^{\mathrm{b}}$ \\
\hline $\begin{array}{l}\text { TIMP1 Ab-7 (clone 2A5), mouse monoclonal } \\
\text { antibody }\end{array}$ & Neomarkers & Prediluted (buffer) & LSAB+System-HRP, Dako & Percentage and intensity ${ }^{\mathrm{b}}$ \\
\hline $\begin{array}{l}\text { TIMP2 Ab-5 (clone 3A4), mouse monoclonal } \\
\text { antibody }\end{array}$ & Neomarkers & Prediluted (buffer) & Ventana, Nexes & Percentage and intensity ${ }^{\mathrm{b}}$ \\
\hline TIMP3 Ab-1, rabbit polyclonal antibody & Neomarkers & Prediluted (buffer) & Ventana, Nexes & Percentage and intensity ${ }^{\mathrm{b}}$ \\
\hline TIMP4 Ab-1, rabbit polyclonal antibody & Neomarkers & Prediluted (buffer) & Ventana, Nexes & Percentage and intensity ${ }^{\mathrm{b}}$ \\
\hline$\beta$-Catenin (E-5), mouse monoclonal & Santa Cruz Biotechnology & $1: 100$ & $\begin{array}{l}\text { Dako } \\
\text { Autostainer }\end{array}$ & Percentage $^{\mathrm{a}}$ \\
\hline $\begin{array}{l}\text { Anti-human CD } 44 \text { hematopoietic, mouse } \\
\text { monoclonal antibody }\end{array}$ & $\begin{array}{l}\text { R\&D Systems Europe, Abingdon, } \\
\text { UK }\end{array}$ & $1: 1000$ & Ventana, Nexes & Percentage and intensity ${ }^{\mathrm{b}}$ \\
\hline $\begin{array}{l}\text { Anti-human CD44 variant } 3 \text {, mouse } \\
\text { monoclonal antibody }\end{array}$ & R\&D Systems Europe & $1: 600$ & Ventana, Nexes & Percentage and intensity ${ }^{\mathrm{b}}$ \\
\hline $\begin{array}{l}\text { Anti-human CD } 44 \text { variant } 6 \text {, mouse } \\
\text { monoclonal antibody }\end{array}$ & R\&D Systems Europe & $1: 1000$ & Ventana, Nexes & Percentage and intensity ${ }^{\mathrm{b}}$ \\
\hline $\begin{array}{l}\text { Purified anti-MLH-1, mouse monoclonal } \\
\text { antibody }\end{array}$ & BD Biosciences, San José, CA, USA & $1: 50$ & $\begin{array}{l}\text { Dako } \\
\text { Autostainer }\end{array}$ & $\begin{array}{l}0 \text { : Total absence of nuclear staining } \\
\text { 1: Presence of staining }\end{array}$ \\
\hline $\begin{array}{l}\text { Purified anti-MSH-2, mouse monoclonal } \\
\text { antibody }\end{array}$ & BD Pharmingen & $1: 200$ & $\begin{array}{l}\text { Dako } \\
\text { Autostainer }\end{array}$ & $\begin{array}{l}\text { 0: Total absence of nuclear staining } \\
\text { 1: Presence of staining }\end{array}$ \\
\hline $\begin{array}{l}\text { MSH6/GTBP, IgG1 mouse monoclonal } \\
\text { antibody }\end{array}$ & BD Biosciences, San José, CA, USA & $1: 100$ & Dako Autostainer & $\begin{array}{l}\text { 0: Total absence of nuclear staining } \\
\text { 1: Presence of staining }\end{array}$ \\
\hline $\begin{array}{l}\text { Purified anti-PMS2, mouse monoclonal } \\
\text { antibody }\end{array}$ & BD Pharmingen & $1: 60$ & Ventana, Nexes & $\begin{array}{l}\text { 0: Total absence of nuclear staining } \\
\text { 1: Presence of staining }\end{array}$ \\
\hline
\end{tabular}

${ }^{\mathrm{a}}$ Percentage: The number of positive cells was scored as follows: $0:<2 \% ; 1: 2-24 \% ; 2: 25-50 \%$; and $3:>50 \%$.

${ }^{\mathrm{b}}$ Percentage and intensity: After evaluating separately the percentage of positive cells $\mathrm{s}^{\mathrm{a}}$ and the intensity of staining ${ }^{\mathrm{c}}$, the two values were added and the final values were scored as follows: 0 : absent; 1 : 2 or $3(1+1,2+1$, or $1+2) ; 2: 4(1+3,3+1$, or $2+2)$; and $3: 5$ or $6(2+3,3+2$, or $3+3)$

${ }^{\mathrm{C}}$ Intensity: The degree of intensity was evaluated as follows: 1: faint; 2: moderate; and 3: intense. 
footnote of Table 1 . The results of synaptophysin were firstly evaluated considering percentage and intensity, but a binary score was also assessed using $10 \%$ of positive cells as cutoff point. Owing to the difficulty on accurately quantifying the percentage of vascular endothelial growth factor (VEGF)-positive cells, the cases were classified as negative, high expression ( $>50 \%)$, or low expression $(\leq 50 \%)$. Cytokeratin 20 expression was evaluated as a binary variable using $1 \%$ as cutoff point to differentiate cases with negative or very low expression from positive cases. Finally, as the abnormal expression of the mismatch repair gene proteins (MLH-1, MSH2, MSH-6, or PMS-2) consists in a total absence of staining, this variable was also binary (absence/ presence). For every case, all parameters (Table 1) were first independently evaluated by each of two authors (MTFF and EM) and then jointly reevaluated under a double-headed microscope for final score agreement.

\section{Statistical Study}

Immunohistochemical expression of each marker was assessed in the tissue array (two cylinders for each case) and the results were averaged. Statistical analysis was carried out using SPSS (V11.5) software (SPSS Inc., Chicago, IL, USA), with two-sided tests. Cases of Merkel cell carcinoma were classified according to evolution as 'good prognosis' or 'aggressive' (Merkel cell carcinomas with good prognosis corresponded to disease-free patients and aggressive Merkel cell carcinomas to cases developing metastases). The statistical significance of differences in immunohistochemical expression levels of the different markers was evaluated using Student's $t$-test and Mann-Whitney test. Differences between groups were considered to be statistically significant when the $P$-value was less than 0.05 . Fisher's exact test was used to determine the statistical significance of differences between proportions in binary variables and in binary- transformed variables (the latter were those variables for which a statistically significant difference or trend was found; they were subsequently recoded). The Spearman correlation coefficient with $95 \%$ confidence limits was used to test the association strength between the different antibodies expression levels.

\section{Results}

The significant results provided by the statistical analysis are summarized in Tables 2 and 3. No statistically significant association was found between the scores of synaptophysin expression and prognosis. Nevertheless, we observed that all four cases with synaptophysin expression in less than $10 \%$ of tumor cells had good prognosis. By using this binary variable, a significant association $(P=0.0301$, Fisher's exact test) was identified between low synaptophysin expression (Figure 1a) and good prognosis. As for other markers of neuroendocrine differentiation, chromogranin showed the lowest scores and the highest scores corresponded to CD56 (Figure 1b), but no statistically significant differences were found in regard to prognosis. This was also the case with cytokeratin 20 .

The cell cycle markers P53, P21, Bcl-2, and Bcl-6 were not shown to have prognostic value. Overexpression of P53 was observed in cases from both groups. More than 5\% of cells were positive for P21 in most Merkel cell carcinomas (Figure 2a), but the percentage of positive cells was usually under $50 \%$. Cases of Merkel cell carcinoma associated with bad prognosis tended to show higher P21 expression levels $(P=0.058)$. Bcl-2 overexpression was almost universal. An inverse correlation between P53 and Bcl-2 expression was not observed. Bcl-6 expression was completely negative in all the lesions studied. All cases of Merkel cell carcinoma expressed KIT (CD117) to greater or lesser extent, but variations in intensity were not significantly associated with prognosis.

Table 2 Immunohistochemical markers for which a trend or statistically significant $(P<0.05$, bold $)$ association with prognosis of Merkel cell carcinoma was found

\begin{tabular}{|c|c|c|c|c|}
\hline Marker & $\begin{array}{c}\mathrm{P} \text { (Mann-Whitney } \\
\text { test) }\end{array}$ & $\begin{array}{l}\mathrm{P} \text { (Fisher's exact test) } \\
\text { for binary variables }\end{array}$ & $\begin{array}{l}\text { Expression scores of } \\
\text { bad prognosis group of } \\
\text { Merkel cell carcinomas } \\
\quad \text { (mean } \pm \text { s.d.) }\end{array}$ & $\begin{array}{c}\text { Expression scores of good } \\
\text { prognosis group of Merkel } \\
\text { cell carcinomas } \\
\text { (mean } \pm \text { s.d.) }\end{array}$ \\
\hline Synaptophysin & & 0.0301 & & \\
\hline $\mathrm{P} 21$ & 0.0581 & & $1.62 \pm 0.81$ & $1.07 \pm 0.70$ \\
\hline NF-kappaB (stromal) & 0.0342 & & $1.87 \pm 1.09$ & $1.00 \pm 1.18$ \\
\hline P38 & 0.0263 & & $1.56 \pm 0.89$ & $0.87 \pm 0.64$ \\
\hline $\begin{array}{l}\text { Prostaglandin E } \\
\text { synthase } 1 \text { (extension) }\end{array}$ & 0.0528 & & $2.87 \pm 0.62$ & $3.33 \pm 0.72$ \\
\hline VEGF & 0.0189 & & $1.21 \pm 0.70$ & $0.54 \pm 0.66$ \\
\hline MMP7 & 0.0107 & & $2.75 \pm 0.58$ & $2.15 \pm 0.69$ \\
\hline MMP10/2 & 0.0240 & & $0.69 \pm 0.79$ & $0.13 \pm 0.35$ \\
\hline TIMP3 & 0.0394 & & $1.60 \pm 0.63$ & $1.07 \pm 0.62$ \\
\hline
\end{tabular}


Table 3 Immunohistochemical markers with expression levels showing statistically significant correlation (Spearman's $\rho$, $P<0.05)$ in Merkel cell carcinoma

\begin{tabular}{llcl}
\hline Marker & Marker & Spearman's $\rho$ & P-value \\
\hline Synaptophysin & P38 & 0.3760 & 0.0444 \\
P53 & P38 & 0.3980 & 0.0266 \\
P21 & NF-kappaB & 0.4489 & 0.0128 \\
& (stromal) & & \\
P21 & MMP7 & 0.3730 & 0.0463 \\
NF-kappaB & P21 & 0.4489 & 0.0128 \\
(stromal) & & & \\
P38 & Synaptophysin & 0.3760 & 0.0444 \\
P38 & P53 & 0.3980 & 0.0266 \\
P38 & MMP7 & 0.3679 & 0.0496 \\
VEGF & MMP7 & 0.4048 & 0.0447 \\
VEGF & MMP10/2 & 0.5607 & 0.0024 \\
MMP7 & P21 & 0.3730 & 0.0463 \\
MMP7 & P38 & 0.3679 & 0.0496 \\
MMP7 & VEGF & 0.4048 & 0.0447 \\
MMP10/2 & VEGF & 0.5607 & 0.0024 \\
\hline
\end{tabular}

A low percentage of cells were PTEN-positive in all but one case of Merkel cell carcinoma, in which both the primary lesion and metastases showed strong and diffuse (score $=3$ ) PTEN expression. This same case of Merkel cell carcinoma exhibited marked P53 overexpression. Nuclear expression of NF-kappaB transcription factor in Merkel cell carcinoma cells ranged from absent to faintly positive. Conversely, the stroma of many tumors exhibited a strong NF-kappaB immunoreactivity, but cases with bad prognosis had significantly higher scores $(P=0.0342$, rank sum test). Levels of NF-kappaB expression in tumor stroma (Figure 2b) correlated significantly with P21 expression (Spearman's $\rho=0.4489, P=0.0128$ ).

Survivin was expressed in many cases and was not significantly associated with prognosis. Positive staining for P38 (Figure 3) was present in most Merkel cell carcinomas in both groups, but P38
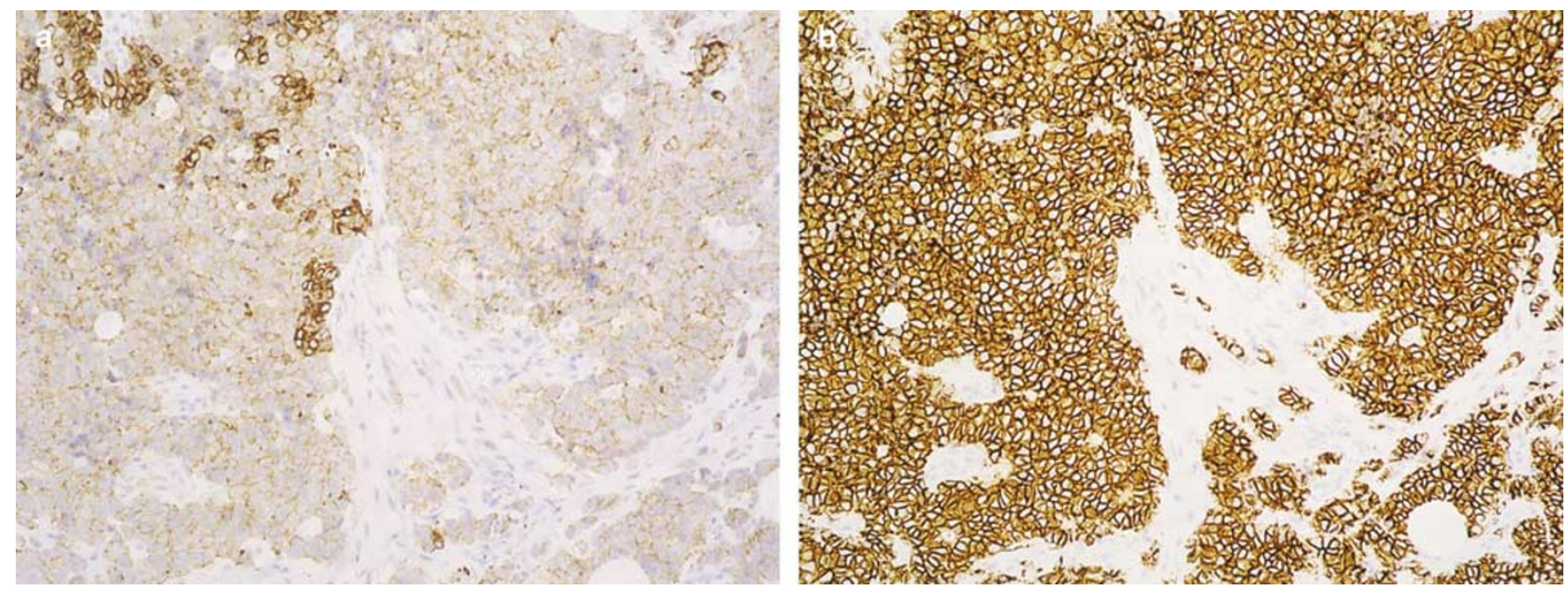

Figure 1 (a) Merkel cell carcinomas showing more than 10\% synaptophysin-positive cells had a significant worse prognosis. (b) In most cases, CD56 was the most sensitive neuroendocrine differentiation marker. However, neither the percentage of positive cells nor the intensity of staining correlated with prognosis.
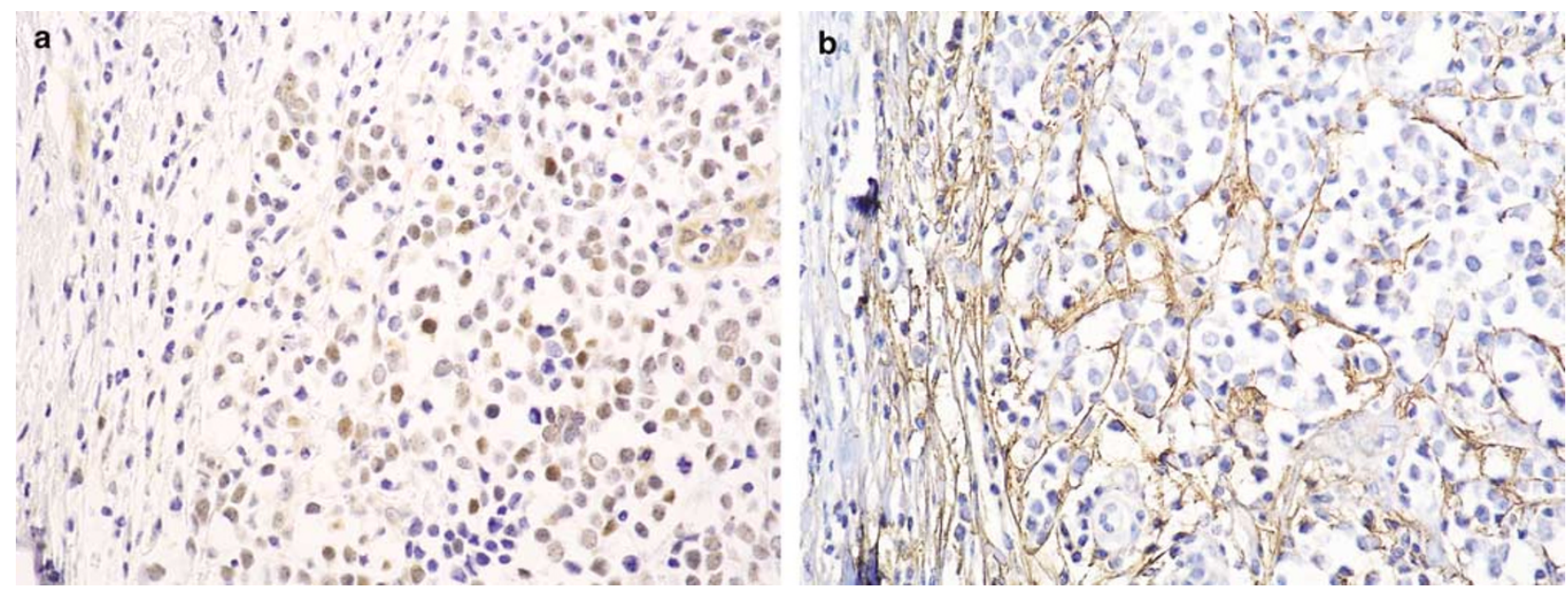

Figure 2 (a) In most cases of Merkel cell carcinoma, P21 was expressed in more than $25 \%$ of cells. Higher expression levels of P21 tended to be associated with a worse prognosis and correlated with (b) higher levels of stromal NF-kappaB. 


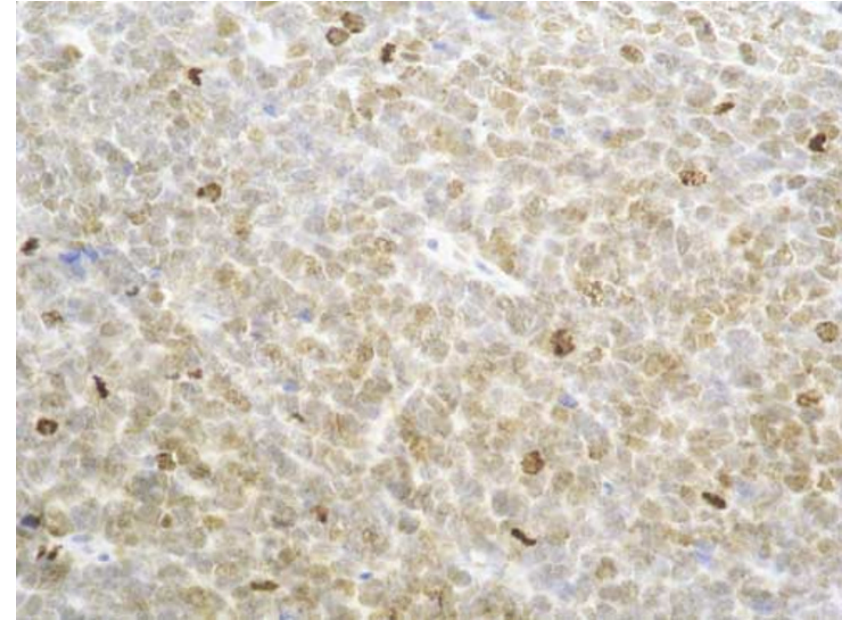

Figure 3 Phosphorylated P38 was expressed in most cases of Merkel cell carcinoma. Intensity of immunostaining and percentage of positive cells were significantly correlated with a worse prognosis.

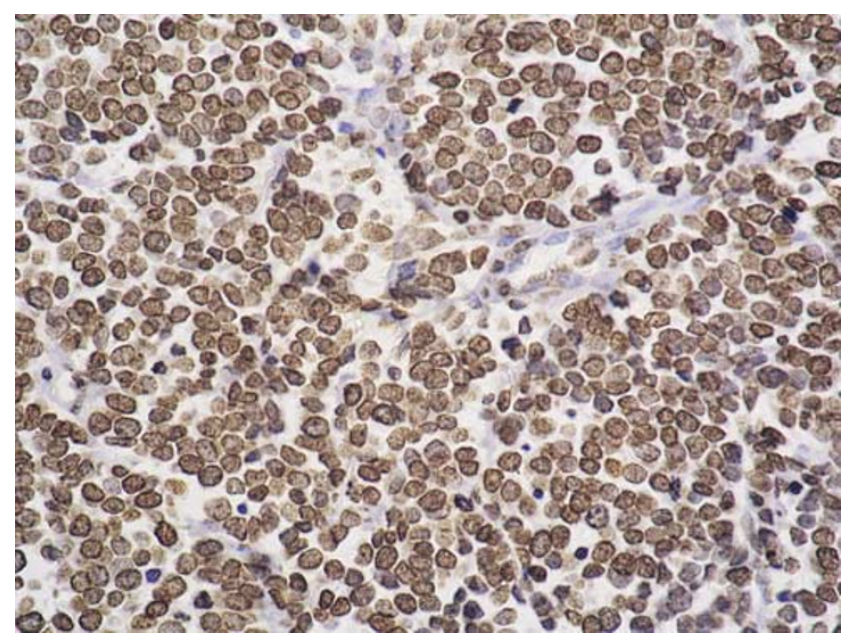

Figure 4 MMP7 expression levels were elevated in most cases of Merkel cell carcinoma and were significantly correlated with adverse outcome.

scores ranked significantly higher in cases with bad prognosis $(P=0.0263)$. The expression levels of P38 were significantly correlated with those of synaptophysin (Spearman's $\rho=0.3760, P=0.0444$ ), P53 (Spearman's $\rho=0.3980, \quad P=0.0266$ ), and MMP7 (Spearman's $\rho=0.3679, P=0.0496$ ).

As regards the expression of prostaglandin $E$ synthases 1 and 2, there was great variability and no significant association with tumor progression was identified. Only two cases showed high hypoxia-inducible factor (HIF)- $1 \alpha$ expression levels, which were not related to tumor progression. In spite of the relatively weak intensity of the staining obtained for VEGF, we found a significant association $(P=0.0189)$ between higher scores and aggressive behavior. The expression of VEGF receptor-2 (FLK) was very variable, ranging from high to absent. No significant correlation was found with the clinical course of Merkel cell carcinomas.

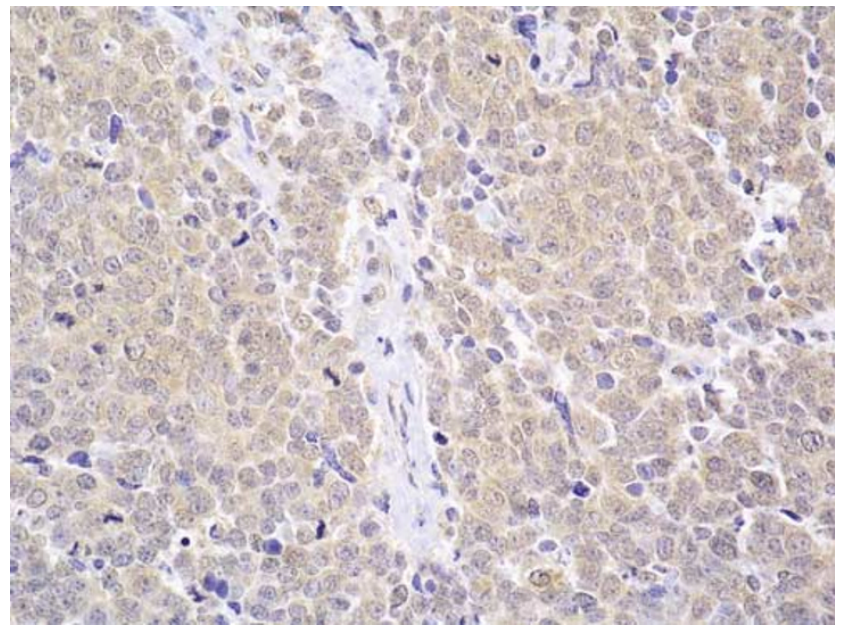

Figure 5 MMP10 expression levels in Merkel cell carcinomas were significantly higher in the cases with metastatic spread.

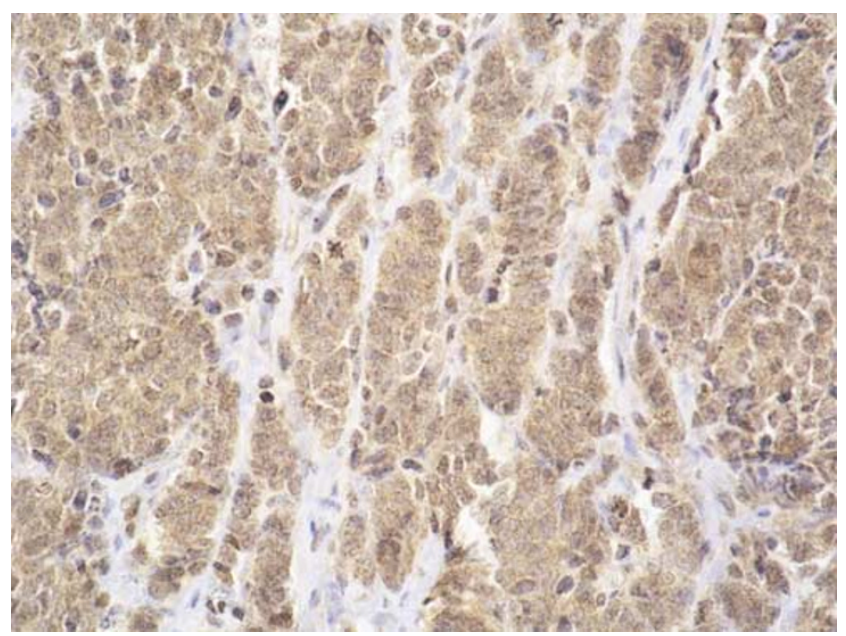

Figure 6 TIMP3 expression was present in most Merkel cell carcinomas and was significantly correlated with an aggressive evolution.

Expression of standard CD44 and its variants V3 and V6 was variable and not statistically associated with evolution of Merkel cell carcinoma. No correlation was found between $\beta$-catenin expression and evolution of prognosis; aberrant nuclear expression was seen only in one case, which did not develop metastases.

All MMPs, but MMP19, were expressed in tumor cells of Merkel cell carcinomas. MMP13 showed only a slight staining in two cases of Merkel cell carcinoma belonging to the good prognosis group and one instance of Merkel cell carcinoma with bad prognosis. MMP7 overexpression (Figure 4) was significantly associated with bad prognosis $(P=0.0107)$, as was the case with MMP10/2 $(P=0.024)$ (Figure 5), but no statistically significant differences in expression levels of the other MMPs studied were found. Expression levels of VEGF were significantly correlated with those of both MMP7 
(Spearman's $\rho=0.4489, P=0.0128$ ) and MMP10/2 (Spearman's $\rho=0.5602, P=0.0024$ ). Additionally, expression levels of MMP7 were significantly correlated with those of P21 (Spearman's $\rho=0.3730$, $P=0.0463$ ) and P38 (Spearman's $\rho=0.3679$, $P=0.0496$ ). As regards TIMPs, all Merkel cell carcinomas with good prognosis, except two, stained for TIMP3 (Figure 6), which was also detected with a significantly higher score in every case of Merkel cell carcinoma with bad prognosis $(P=0.0394)$. Only six cases of Merkel cell carcinoma were positive for TIMP1 and five cases for TIMP2, all of them with low scores. The differences among TIMP1, TIMP2, or TIMP4 expression levels were not statistically significant. Finally, none of the cases showed alterations in the expression of the DNA mismatch repair gene proteins associated with hereditary non-polyposis colon cancer (MLH-1, MSH-2, MSH-6, or PMS-2).

In summary, significant associations were found between metastatic tumor spread and high expression levels of MMP7, MMP10/2, TIMP3, VEGF, P38, stromal NF-kappaB, and synaptophysin. There were statistically significant correlations between expression levels of MMP7 and those of VEGF, P21, and P38. The following expression levels were also found to be correlated: MMP10/2 and VEGF, P38 and synaptophysin, P38 and P53, and P21 and stromal NF-kappaB.

\section{Discussion}

Merkel cell carcinoma is probably the most aggressive cutaneous malignancy. ${ }^{2-4,13}$ Its histogenetic origin has been widely debated, although current evidence supports the hypothesis that Merkel cell carcinoma, as well as normal Merkel cells, originates from epithelial cells in either the epidermal basal layer or the adnexa or eventuates from a primitive cutaneous epithelial precursor. ${ }^{14}$ This hypothesis is supported by the existence of features common to both Merkel cell carcinoma and cutaneous squamous cell carcinoma, such as their tendency to appear in sun-damaged skin of elderly people and their sharing of identical UV-typespecific p53 and Ha-ras mutations. ${ }^{8}$ Conversely, Merkel cell carcinoma exhibits similarities with extracutaneous small cell carcinoma that are not only of a morphological or immunohistochemical kind but also include some intrinsic sensitivity to ionizing radiation and chemotherapy, as well as a high metastatic potential. ${ }^{13}$ Therefore, Merkel cell carcinoma seems to occupy an intermediate position between cutaneous squamous cell carcinoma and extracutaneous small cell carcinoma, so that Merkel cell carcinoma is much more aggressive than the former but less so than the latter. ${ }^{2-5}$

Neuroendocrine differentiation is considered to carry a negative prognostic connotation in some carcinomas, ${ }^{15}$ whereas other carcinoma types have yielded contradictory results ${ }^{16,17}$ or shown just a trend toward an association between neuroendocrine differentiation and high tumor grade. ${ }^{18} \mathrm{We}$ found a statistically significant association of low ( $<10 \%$ of tumor cells) expression of synaptophysin with good outcome in Merkel cell carcinoma. Moreover, chromogranin A expression scores ranked higher in the group of cases of Merkel cell carcinoma with aggressive behavior, although this difference did not reach statistical significance. Nevertheless, we found the highest extension and intensity scores when using CD56 antibody, which corroborates the contention that this is a useful marker for Merkel cell carcinoma, ${ }^{19}$ although it would be convenient to use it in combination with other markers that allow confirmation of the neuroendocrine nature of the neoplasm. Our results differ from those of a previous study, ${ }^{20}$ in which the expression of neuroendocrine markers in Merkel cell carcinoma cells was seen to be associated with good prognosis. In addition, very low cytokeratin 20 expression was associated with good prognosis in our series.

Most Merkel cell carcinomas in our series were positive for Bcl-2, P53, and KIT (CD117) but, as in previous studies, ${ }^{21,22}$ no association with prognosis was found. Bcl-6, normally present in the epidermal prickle layer and also detected in well-differentiated cutaneous squamous cell carcinoma, ${ }^{23}$ was steadily negative in our series of Merkel cell carcinomas. This supports the assumption that Bcl-6 expression is associated with squamous cell maturation. ${ }^{23}$ The tumor suppressor gene $p 21$, which to the best of our knowledge has never been previously studied in Merkel cell carcinoma, was also widely positive in most of our instances of Merkel cell carcinoma, and its expression levels tended to be associated with a bad prognosis.

In regard to the PI3-K pathway, alterations of $N F$ kappaB and PTEN are frequently found in human tumors of diverse origin. Activation of $N F-k a p p a B$ providing resistance to chemotherapy and radiotherapy has been described in cutaneous squamous cell carcinoma, ${ }^{24}$ but seems to play a minor role in Merkel cell carcinoma. Nevertheless, we detected NF-kappaB overexpression in 'reactive' intratumoral myofibroblasts, probably a reflection of the stromal transformation associated with carcinogenesis. ${ }^{25}$ The correlation between P21 and stromal NFkappaB expression levels that we found can be explained by the ability of NF-kappaB to induce P21 expression. ${ }^{26}$ In our cases of Merkel cell carcinoma, there was downregulation of the tumor suppressor $P T E N$. In contrast to some findings in extracutaneous small cell carcinoma of the lung, ${ }^{27}$ it has been previously shown that the incidence of PTEN mutations in Merkel cell carcinoma is low. ${ }^{28}$ Thus, we can hypothesize that PTEN gene inactivation is caused by other transcriptional or posttranscriptional mechanisms, such as the promoter methylation seen in non-small cell carcinoma of the lung. ${ }^{29}$ 
All our cases of Merkel cell carcinoma showed high rates of nuclear survivin expression, independently of their benign or aggressive evolution. Survivin is overexpressed in many cancers, usually translocated to the nucleus, and associated with metastatic spread, resistance to chemotherapy and bad prognosis. ${ }^{30-33}$ In some tissues neuroendocrine differentiation seems to induce survivin activation. ${ }^{31,32}$ Our results suggest that survivin contributes to Merkel cell carcinoma development but has no independent impact on the metastatic spread of the neoplasm. Of interest, in Merkel cell carcinoma PTEN downregulation might contribute to survivin overexpression, an association also described in high-grade tumors from other locations. ${ }^{33}$

MAPKs are involved in cell differentiation, proliferation, and apoptosis. ${ }^{34}$ Three main MAPK pathways are known in humans: the extracellular signal-regulated kinase (ERK) pathway, the C-Jun $\mathrm{NH}_{2}$-terminal kinase (JNK) pathway, and the P38 pathway. ${ }^{34}$ Whereas P38 and JNK are better known by their role in the inflammatory and immune responses, ${ }^{34,35}$ many studies have demonstrated ERK activation in human cancers. ${ }^{35,36}$ Nevertheless, all three MAPK pathways seem to be involved in carcinogenesis and recent evidence suggests that $\mathrm{P} 38 \lambda$, one of the four P38 isoforms (P38 $\alpha$, P38 $\beta$, $\mathrm{P} 38 \kappa$, and $\mathrm{P} 38 \lambda),{ }^{36}$ is instrumental in malignant transformation linked to $K$-ras mutations. In a study of Merkel cell carcinoma, the ERK pathway was completely inactive in 42 of 44 cases, ${ }^{37}$ but no information on the P38 pathway was provided. In the present study, there was immunopositivity for phosphorylated P38 in 26 of 31 cases of Merkel cell carcinoma. Additionally, expression levels of P38 were seen to be significantly correlated with those of synaptophysin, P53, and MMP-7, and cases of Merkel cell carcinoma with bad prognosis showed significantly higher expression levels of P38.

Aberrantly increased cyclooxygenase-2 (COX-2), found in many carcinomas, is an early event in tumorigenesis. ${ }^{38}$ Both phosphorylated P38 and UV exposure can increase cellular levels of COX-2. In spite of the influence exerted by both mechanisms in most cases of Merkel cell carcinoma, low levels of COX-2 in Merkel cell carcinoma were found in a previous study. ${ }^{39}$ In view of this, we decided to explore the expression of two enzymes downstream of COX-2 (microsomal prostaglandin E synthases 1 and 2) and found low expression levels that were unrelated to biologic behavior, even though microsomal prostaglandin E synthase 1 expression tended to be more extensive in Merkel cell carcinomas with good prognosis.

HIF-1, a transcription factor, is overexpressed in some human cancers $^{40}$ and can influence target genes such as the VEGF. ${ }^{41}$ In our cases of Merkel cell carcinoma we could not demonstrate activation of the HIF pathway, the intensity of VEGF staining being faint in most cases. Even so, our aggressive Merkel cell carcinomas showed significantly higher
VEGF expression levels and, interestingly enough, VEGF expression in our series was statistically correlated with that of two MMPs (MMP-7 and MMP-10/2), which also showed higher expression scores in aggressive cases. On the other hand, expression of VEGF receptor 2 (FLK-1) was variable in our cases of Merkel cell carcinoma. These results suggest a likely role of VEGF signal pathway in Merkel cell carcinoma tumor progression and the potential benefit of using anticancer treatments targeted on these molecules.

Albeit a previous study ${ }^{42}$ reported the expression of cell adhesion molecule CD44 in Merkel cell carcinoma and suggested that its loss might be related to tumor dissemination; our results do not confirm this contention. We found highly variable (from absent to strongly positive) expression of standard CD44 and CD44 variants V3 and V6 in our cases of Merkel cell carcinoma, independently of their evolution.

The physiological roles of $\beta$-catenin include not only cell adhesion and maintenance of tissue architecture and polarity, but also transcriptional activation. ${ }^{43}$ Mutations of the $\beta$-catenin gene, CTNNB1, may lead to expression loss or aberrant nuclear accumulation. Whereas $\beta$-catenin loss causes decreased cell adhesion and facilitates metastatic spread, nuclear translocation has a proliferative effect. ${ }^{43}$ Both alterations have been described in tumors arising in different organs, including neuroendocrine lung carcinomas, ${ }^{44}$ and are usually associated with poorer survival. ${ }^{43-45}$ Decreased or aberrant expression of $\beta$-catenin was a frequent finding in our cases of Merkel cell carcinoma and confirms previous reports of altered adhesion molecule profiles in Merkel cell carcinoma and their likely role in the development of this neoplasm. ${ }^{46}$

MMPs and their tissue inhibitors, a large group of molecules involved in a variety of physiological processes, seem to have an important function in metastatic spread, although their expression in Merkel cell carcinoma has been only occasionally explored. ${ }^{47}$ The concentration of most MMPs and TIMPs is regulated at transcriptional and posttranscriptional levels and immunohistochemistry is a good method to evaluate their expression. ${ }^{48}$ In a previous work on 23 cases of Merkel cell carcinoma, a statistically significant correlation was found between high MMP1 and MMP3 expression levels and metastatic potential, whereas MMP7 was not evaluated. ${ }^{47}$ Upregulation of MMP7 (matrilysin), a predictor of poor outcome in several neoplasms, is correlated with stage in non-small cell lung carcinoma ${ }^{49}$ and has been described in high-grade neuroendocrine lung tumors. ${ }^{50}$ Moreover, the $M M P 7-181 A / G$ polymorphism seems to be related to a higher risk of developing certain carcinomas. ${ }^{51}$ In our study, we found high expression levels of most metalloproteinases, but only those of MMP7 and MMP10 were significantly 
related to bad prognosis. There was a significant correlation between the expression levels of MMP7 and those of VEGF, P21, and P38. Upregulation of MMP10 (stromelysin 2), also an unfavorable prognostic factor in many neoplasms, ${ }^{49}$ was significantly associated with an aggressive outcome and correlated with VEGF expression levels in the present study.

Regarding TIMPs, TIMP1 has been shown to be overexpressed and associated with poor outcome in many human malignancies, ${ }^{52}$ but this was not the case in our series. As for TIMP2, it does not seem to play a role in Merkel cell carcinoma tumorigenesis. In contrast, we found that TIMP3 overexpression was significantly associated with an adverse outcome. TIMP3 expression loss can be due to hypermethylation or mutant p53-mediated transcriptional repression. In many neoplasms, TIMP3 downregulation is related to tumor invasion and increased angiogenesis, as the binding of VEGF to VEGF receptor-2 is unblocked and downstream signaling is activated. A recent article claims that TIMP3 deficiency in the host, but not in the neoplasm, is responsible for enhancing tumor growth and angiogenesis. ${ }^{53}$ Additionally, in the work by Massi et al, ${ }^{47}$ TIMP3 was seen to be expressed in $91.3 \%$ of Merkel cell carcinoma cases. In other studies, $70-100 \%$ of lung extracutaneous small cell carcinomas cells were immunohistochemically positive for TIMP $3,{ }^{54}$ and TIMP3 overexpression in carcinoma cells was related to a worse prognosis. ${ }^{55,56}$ Finally, we observed a tendency of TIMP4 downregulation to be related to aggressiveness. Low TIMP4 expression has also been described in lung cancer ${ }^{54}$ and seems to be caused by methylation. ${ }^{57}$

None of our Merkel cell carcinomas lacked MLH-1, MSH-2, MSH-6, or PMS2 immunoreactivity. Therefore, the tumors in our series were unrelated to Muir-Torre syndrome or hereditary non-polyposis colon cancer syndrome, which are secondary to germline mutations in the aforesaid genes. ${ }^{58}$

In conclusion, our identification of expression profiles associated with aggressive behavior of Merkel cell carcinoma may be helpful in predicting the clinical course of Merkel cell carcinoma and potentially useful for the development of much needed therapies against the most aggressive of skin neoplasms.

\section{Acknowledgement}

We thank Professor Ignasi Gich (Department of Clinical Epidemiology, Hospital Santa Creu i Sant $\mathrm{Pau}$, Barcelona) for his assistance with statistics and the Department of Pathology, Hospital de la Creu Roja, Barcelona, for providing one of the cases of Merkel cell carcinoma studied. Supported by FIS Grant 02/0514, DURSI Grant 2005-SGR828 and RTIC Grant 03-10.

\section{References}

1 Moll I, Zieger W, Schmelz M. Proliferative Merkel cells were not detected in human skin. Arch Dermatol Res 1996;288:184-187.

2 Allen PJ, Bowne WB, Jaques DP, et al. Merkel cell carcinoma: prognosis and treatment of patients from a single institution. J Clin Oncol 2005;23:2300-2309.

3 Agelli M, Clegg LX. Epidemiology of primary Merkel cell carcinoma in the United States. J Am Acad Dermatol 2003;49:832-841.

4 Skelton HG, Smith KJ, Hitchcock CL, et al. Merkel cell carcinoma: analysis of clinical, histologic, and immunohistologic features of 132 cases with relation to survival. J Am Acad Dermatol 1997;37:734-739.

5 Tai P, Tonita J, Yu E, et al. Twenty-year follow-up study of long-term survival of limited-stage small-cell lung cancer and overview of prognostic and treatment factors. Int J Radiat Oncol Biol Phys 2003;56:626-633.

6 Van Gele M, Boyle GM, Cook AL, et al. Geneexpression profiling reveals distinct expression patterns for classic versus variant Merkel cell phenotypes and new classifier genes to distinguish Merkel cell from small-cell lung carcinoma. Oncogene 2004;23: 2732-2742.

7 Fernandez-Figueras MT, Puig L, Musulen E, et al. Prognostic significance of p27Kip1, p45Skp2 and Ki67 expression profiles in Merkel cell carcinoma, extracutaneous small cell carcinoma, and cutaneous squamous cell carcinoma. Histopathology 2005;46: 614-621.

8 Llombart B, Monteagudo C, Lopez-Guerrero JA, et al. Clinicopathological and immunohistochemical analysis of 20 cases of Merkel cell carcinoma in search of prognostic markers. Histopathology 2005;46:622-634.

9 Popp S, Waltering S, Herbst C, et al. UV-B-Type mutations and chromosomal imbalances indicate common pathways for the development of Merkel and skin squamous cell carcinomas. Int J Cancer 2002;99:352-360.

10 Vihinen P, Ala-aho R, Kahari VM. Matrix metalloproteinases as therapeutic targets in cancer. Curr Cancer Drug Targets 2005;5:203-220.

11 Milanes-Yearsley M, Hammond EH, Pajak TF, et al. Tissue micro-array: a cost and time-effective method for correlative studies by regional and national cancer study groups. Mod Pathol 2002;15:1366-1373.

12 Rosen DG, Huang X, Deavers MT, et al. Validation of tissue microarray technology in ovarian carcinoma. Mod Pathol 2004;17:790-797.

13 Poulsen MG. Merkel-cell carcinoma of the skin. Lancet Oncol 2004;10:593-599.

14 Sidhu GS, Chandra P, Cassai ND. Merkel cells, normal and neoplastic: an update. Ultrastruct Pathol 2005; 29:287-294.

15 Hong SM, Kim MJ, Pi DY, et al. Neuroendocrine differentiation in extrahepatic bile duct carcinomas and its prognostic significance. Hum Pathol 2005;36: 732-740.

16 Howe MC, Chapman A, Kerr K, et al. Neuroendocrine differentiation in non-small cell lung cancer and its relation to prognosis and therapy. Histopathology 2005;46:195-201.

17 Pelosi G, Pasini F, Sonzogni A, et al. Prognostic implications of neuroendocrine differentiation and hormone production in patients with Stage I nonsmall cell lung carcinoma. Cancer 2003;97:2487-2497. 
18 van Krimpen C, Elferink A, Broodman CA, et al. The prognostic influence of neuroendocrine differentiation in breast cancer: results of a long-term follow-up study. Breast 2004;13:329-333.

19 Kurokawa M, Nabeshima K, Akiyama Y, et al. CD56: a useful marker for diagnosing Merkel cell carcinoma. J Dermatol Sci 2003;31:219-224.

20 Koljonen V, Haglund C, Tukiainen E, et al. Neuroendocrine differentiation in primary Merkel cell carcinomapossible prognostic significance. Anticancer Res 2005; 25:853-858.

21 Kennedy MM, Blessing K, King G, et al. Expression of bcl-2 and p53 in Merkel cell carcinoma. An immunohistochemical study. Am J Dermatopathol 1996;18: 273-277.

22 Feinmesser M, Halpern M, Kaganovsky E, et al. c-kit expression in primary and metastatic Merkel cell carcinoma. Am J Dermatopathol 2004;26: 458-462.

23 Kanazawa N, Moriyama M, Onizuka T, et al. Expression of bcl-6 protein in normal skin and epidermal neoplasms. Pathol Int 1997;47:600-607.

24 Kobielak A, Fuchs E. Links between alpha-catenin, NF-kappaB, and squamous cell carcinoma in skin. Proc Natl Acad Sci USA 2006;103:2322-2327.

25 Vandoros GP, Konstantinopoulos PA, SotiropoulouBonikou G, et al. PPAR-gamma is expressed and NF-kB pathway is activated and correlates positively with COX-2 expression in stromal myofibroblasts surrounding colon adenocarcinomas. J Cancer Res Clin Oncol 2006;132:76-84.

26 Chang PY, Miyamoto S. Nuclear factor-kappaB dimer exchange promotes a p21(waf1/cip1) superinduction response in human $\mathrm{T}$ leukemic cells. Mol Cancer Res 2006;4:101-112.

27 Yokomizo A, Tindall DJ, Drabkin H, et al. PTEN/ MMAC1 mutations identified in small cell, but not in non-small cell lung cancers. Oncogene 1998;17: 475-479.

28 Soria JC, Lee HY, Lee JI, et al. Lack of PTEN expression in non-small cell lung cancer could be related to promoter methylation. Clin Cancer Res 2002;8: 1178-1184.

29 Van Gele M, Leonard JH, Van Roy N, et al. Frequent allelic loss at $10 \mathrm{q} 23$ but low incidence of PTEN mutations in Merkel cell carcinoma. Int J Cancer 2001;92:409-413.

30 Fukuda S, Pelus LM. Survivin, a cancer target with an emerging role in normal adult tissues. Mol Cancer Ther 2006;5:1087-1098.

31 Mosca A, Berruti A, Russo L, et al. The neuroendocrine phenotype in prostate cancer: basic and clinical aspects. J Endocrinol Invest 2005;28:141-145.

32 Grabowski P, Griss S, Arnold CN, et al. Nuclear survivin is a powerful novel prognostic marker in gastroenteropancreatic neuroendocrine tumor disease. Neuroendocrinology 2005;81:1-9.

33 Sui L, Dong Y, Watanabe Y, et al. Alteration and clinical relevance of PTEN expression and its correlation with survivin expression in epithelial ovarian tumors. Oncol Rep 2006;15:773-778.

34 Kumar S, Boehm J, Lee JC. p38 MAP kinases: key signalling molecules as therapeutic targets for inflammatory diseases. Nat Rev 2003;2:717-725.

35 Vicent S, Garayoa M, Lopez-Picazo JM, et al. Mitogenactivated protein kinase phosphatase-1 is overexpressed in non-small cell lung cancer and is an independent predictor of outcome in patients. Clin Cancer Res 2004;10:3639-3649.

36 Tang J, Qi X, Mercola D, et al. Essential role of p38gamma in K-Ras transformation independent of phosphorylation. J Biol Chem 2005;280:2391023917.

37 Houben R, Michel B, Vetter-Kauczok CS, et al. Absence of classical MAP kinase pathway signalling in Merkel cell carcinoma. Invest Dermatol 2006;126: 1135-1142.

38 Gauthier ML, Pickering CR, Miller CJ, et al. p38 regulates cyclooxygenase-2 in human mammary epithelial cells and is activated in premalignant tissue. Cancer Res 2005;65:1792-1799.

39 Koljonen V, Lassus P, Tukiainen E, et al. Cyclooxygenase-2 expression in primary Merkel cell carcinoma. J Cutan Pathol 2005;32:55-58.

40 Dales JP, Garcia S, Meunier-Carpentier S, et al. Overexpression of hypoxia-inducible factor HIF-1 alpha predicts early relapse in breast cancer: retrospective study in a series of 745 patients. Int J Cancer 2005; 116:734-739.

41 Tan C, de Noronha RG, Roecker AJ, et al. Identification of a novel small-molecule inhibitor of the hypoxiainducible factor 1 pathway. Cancer Res 2005;65: 605-612.

42 Penneys NS, Shapiro S. CD44 expression in Merkel cell carcinoma may correlate with risk of metastasis. J Cutan Pathol 1994;21:22-26.

43 Mittal K. The 9 lives of beta-catenin. Hum Pathol 2004;35:647-648.

44 Xu HT, Wang L, Lin D, et al. Abnormal beta-catenin and reduced axin expression are associated with poor differentiation and progression in non-small cell lung cancer. Am J Clin Pathol 2006;125:534-541.

45 Nitadori J, Ishii G, Tsuta K, et al. Immunohistochemical differential diagnosis between large cell neuroendocrine carcinoma and small cell carcinoma by tissue microarray analysis with a large antibody panel. Am J Clin Pathol 2006;125:682-692.

46 Tanaka Y, Sano T, Qian ZR, et al. Expression of adhesion molecules and cytokeratin 20 in Merkel cell carcinomas. Endocr Pathol 2004;15:117-129.

47 Massi D, Franchi A, Ketabchi S, et al. Expression and prognostic significance of matrix metalloproteinases and their tissue inhibitors in primary neuroendocrine carcinoma of the skin. Hum Pathol 2003; 34:80-88.

48 Brew K, Dinakarpandian D, Nagase H. Tissue inhibitors of metalloproteinases: evolution, structure and function. Biochim Biophys Acta 2000;1477: 267-283.

49 Kren L, Goncharuk VN, Krenova Z, et al. Expression of matrix metalloproteinases 3, 10 and 11 (stromelysins 1, 2 and 3 ) and matrix metalloproteinase 7 (matrilysin) by cancer cells in non-small cell lung neoplasms. Clinicopathologic studies. Cesk Patol 2006;42:16-19.

50 Pelosi G, Scarpa A, Veronesi G, et al. A subset of highgrade pulmonary neuroendocrine carcinomas shows up-regulation of matrix metalloproteinase-7 associated with nuclear beta-catenin immunoreactivity, independent of EGFR and HER-2 gene amplification or expression. Virch Arch 2005;447:969-977.

51 Zhang J, Jin X, Fang S, et al. The functional polymorphism in the matrix metalloproteinase-7 promoter increases susceptibility to esophageal squamous cell carcinoma, gastric cardiac adenocarcinoma and 
non-small cell lung carcinoma. Carcinogenesis 2005; 26:1748-1753.

52 Wang CS, Wu TL, Tsao KC, et al. Serum TIMP-1 in gastric cancer patients: a potential prognostic biomarker. Ann Clin Lab Sci 2006;36:23-30.

53 Cruz-Muñoz W, Kim I, Khokha R. TIMP-3 deficiency in the host, but not in the tumor, enhances tumor growth and angiogenesis. Oncogene 2006;25:650-655.

54 Michael M, Babic B, Khokha R, et al. Expression and prognostic significance of metalloproteinases and their tissue inhibitors in patients with small-cell lung cancer. J Clin Oncol 1999;17:1802-1808.

55 Tunuguntla R, Ripley D, Sang QX, et al. Expression of matrix metalloproteinase-26 and tissue inhibitors of metalloproteinases TIMP-3 and -4 in benign endome- trium and endometrial cancer. Gynecol Oncol 2003;89: 453-459.

56 Jiang X, Huang X, Li J, et al. Relationship between tissue inhibitors of metalloproteinase and metastasis and prognosis in breast cancer. Zhonghua Wai Ke Za Zhi 2000;38:291-293.

57 Dammann R, Strunnikova M, Schagdarsurengin U, et al. $\mathrm{CpG}$ island methylation and expression of tumourassociated genes in lung carcinoma. Eur J Cancer 2005;41:1223-1236.

58 Hansen TP, Nielsen O, Fenger C. Optimization of antibodies for detection of the mismatch repair proteins MLH1, MSH2, MSH6, and PMS2 using a biotin-free visualization system. Appl Immunohistochem Mol Morphol 2006;14:115-121. 